\title{
Integrated Data Bank Development as Supporting System of Civil Service Management in Middle Vocational School
}

\author{
Dodi Rosadi* \\ Magister Pendidikan Guru Vokasi Universitas Ahmad Dahlan Yogyakarta \\ *Corresponding author, e-mail: dodirosadi114@gmail.com
}

\begin{abstract}
The objectives of this study are: 1) Improved Integrated Data Bank services for staffing data and information; 2) Enhanced support system for data and information service server usage; 3) Improving data and information services that are accurate for Staffing Management. The research method used is Research and Development (R\&D). Data collection techniques using questionnaires and interviews. Product trials were conducted twice, the first trial involved 15 people, the second trial involved 35 people. The results of the study are 1) Integrated Data Bank services for employee data and information can be used effectively and efficiently. This is based on system reliability with a success rate of $100 \%$. In addition, the efficiency test using GTMetrix gives the results of the PageSpeed Grade B (85\%) with a loading rate of the system page 7.4 seconds; 2 ) the support system for the use of data and information service servers runs according to the Integrated Data Bank application; 3) Personnel management data and information services can be used as an accurate staffing database and show that the Integrated Data Bank staffing management information system can be used as a supporting management system for staff at SMK Muhammadiyah Karangpucung; 4) Integrated Data Bank Products have gone through the process of design validation, instrument validation, and product validation through judgment experts and experts, which produce data in the form of Data Flow Diagrams (DFD), Unified Modeling Language (UML) design, and Entity Relationship Diagram Bank designs Integrated Data. Based on the results of the product design validity test showed that the layout (layout), interface (interface), and content (content) of the system itself obtained a final percentage of $84 \%$. Suggestions in this study include 1) Socialization of the Integrated Data Bank system to employees about the existence of this system can be optimized so that all information can be conveyed properly; 2) Integrated Data Bank systems can be utilized optimally to integrate staffing data; 3) Integrated Data Bank System can be developed into a superior product as a staffing database system in the SMK environment.
\end{abstract}

Keywords: Integrated Data Bank, Civil Service Management, Supporting System,

How to Cite: Rosadi, D. (2020). Integrated data bank development as supporting system of civil service management in middle vocational school. Journal of Vocational Education Studies, 3(2), 6172. DOI: https://doi.org/10.12928/joves.v3i2.1790.

\section{INTRODUCTION}

The process of developing data management requires a system that makes it easy for employees to carry out their performance. Schools as one of the government organizations engaged in education require the availability of a management information system that is able to help store and provide data and information as material for determining development policies and strategies as well as for the availability of operational data and information. This system was built in an effort to facilitate human resource management, improve the quality of human resources and staffing management.

An integrated data bank system is a supporting system of an existing system. Systems that are already running in an organization such as administrative systems, financial systems. The integrated data bank system can also be applied as a supporting system for an staffing system. Good staffing management will improve performance to realize the vision that has been set at an institution, especially in a school. The implementation of good staffing management will also increase the effectiveness and efficiency of services. Strategic 
planning in the use of information technology to create a supporting management system that is staffed, integrated and comprehensive.

Use of supporting data information management systems to help school performance. The development of information technology, its development. Modern management systems have many strategic decisions that result from consideration of integrated information data utilization. Support systems in the development of integrated data banks including through a server hosting system. Then, this system will further facilitate performance through the use of a browser application with a multi-platform integrated data bank system.

Vocational High School (SMK) as an educational institution is inseparable from the development of information technology, including the need for an integrated staffing data bank. The development of technology and information that penetrated into SMKs had a positive impact in order to improve the quality of education services. The use of information and communication technology can be used as a means of: (1) academic and non-academic activities, (2) increasing school branding as a form of excellent service.

A few problems often faced by the personnel management showed less accessible database, storage systems and service personnel data is still manual, the search data and information needed in time quickly and accurately, to not use the data bank system based on information technology to support service personnel.

Thus, researchers are interested in conducting research under the title Integrated Bank Data Development as a Supporting Staffing Management System in Vocational Schools. The development of this application has the intent and purpose to provide staffing information that is needed effectively, efficiently, integrated, and faster. In addition, the structuring of information can be carried out regularly, quickly, and precisely in a good report, which will certainly support the service activities and staffing operations.

\section{RESEARCH METHOD}

This research writer uses Research and Development (R\&D) research. According to Sugiyono (2015) the Research and Development research method which will later be abbreviated to $R \& D$ is a research method used to produce certain products, and test the effectiveness of these products. The product is not always in the form of objects or hardware (hardware), such as books, stationery, and other learning tools. However, it can also be in the form of software (M. P. P. Sugiyono, 2016).

Data collection techniques used were using interviews, questionnaires, and measurement software. Meanwhile, data analysis techniques include: 1) data analysis of the usability test results. Measurement of usability instrument reliability was done by testing the alpha cronbach consistency value; 2) data analysis on the results of testing variable functionality. Measurement of functional suitability testing using the Guttman scale. The questionnaire on the Guttman scale only consists of two answers namely, "Yes" or "No"; 3) data analysis of the reliability variable testing results. Testing the reliability variable using WAPT software. Reliability testing with WAPT software has three assessment categories namely, sessions, pages and hits; 4) data analysis of the Efficiency variable test results. Testing the efficiency variable using GTMatrix. Then, the validity of the data used includes the instrument validity and product validity.

\section{RESULTS AND DISCUSSION \\ Result}

The development of an Integrated Data Bank as a supporting system for staffing management in SMK is explained in detail in this chapter. In this study the researchers used Research and Development (R\&D) research which, according to Sugiyono, consisted of 10 
steps, namely (1). potential and problems, (2) data collection, (3) product design, (4) design validation, (5) product revisions, (6) initial product trials, (7) initial product revisions, (8) final product trials, (9) revision of the final product and (10) trial of the final product. Describe the results of each step of the study.

\section{Potential and Problems}

A needs analysis was carried out through preliminary observations and interviews conducted with the Head of Administration, Teachers and Employees at SMK Muhammadiyah Karangpucung. Based on the initial observation and interview activities, several problems related to staffing data management were found, namely (1) poorly controlled data, (2) paper data, (3) employee data search when needed in quick time, (4) employee data report is less effective and efficient, and (5) databases that are difficult to access.

\section{Data Collection}

The results at the stage of discovering the potential and problems that exist in SMK Muhammadiyah Karangpucung, then the next is to collect data that will be used to build an Integrated Data Bank staffing management system. Data collection is performed on staffing data and also supporting tools used to build the system.

\section{Product Design}

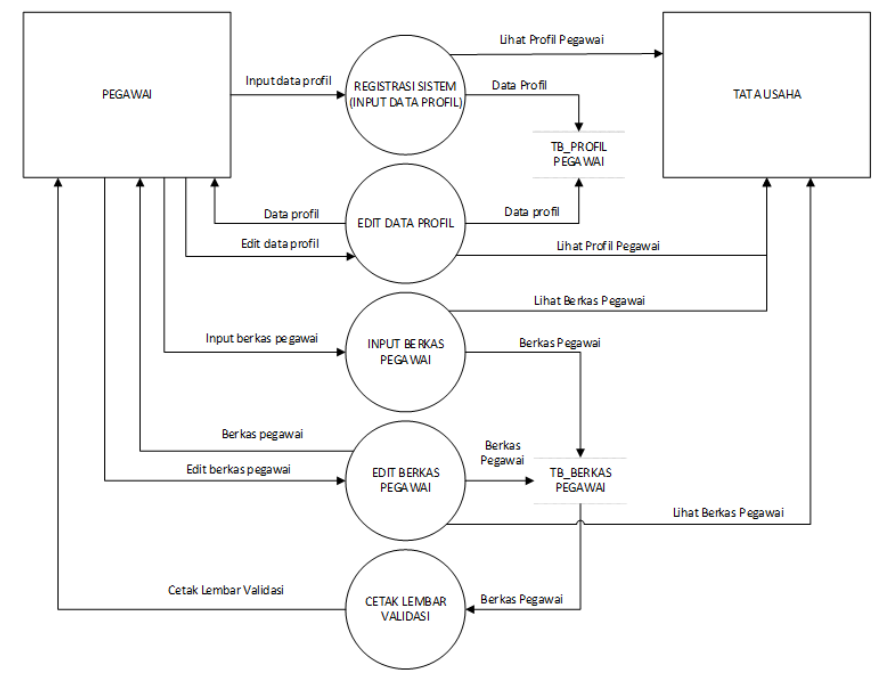

Figure 1. Data Flow Design Using Data Flow Diagrams (DFD) 


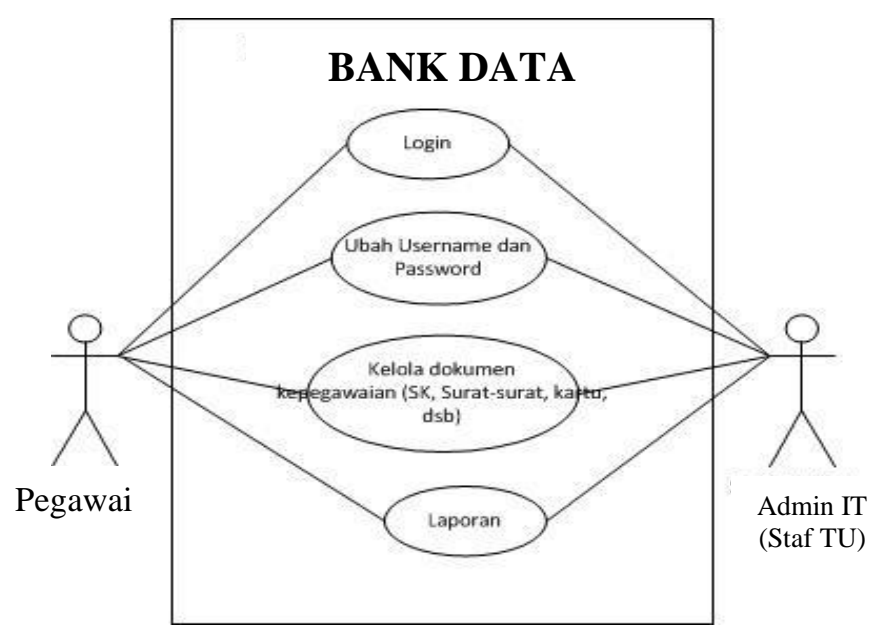

Figure 2. Unified Modeling Language (UML) Design

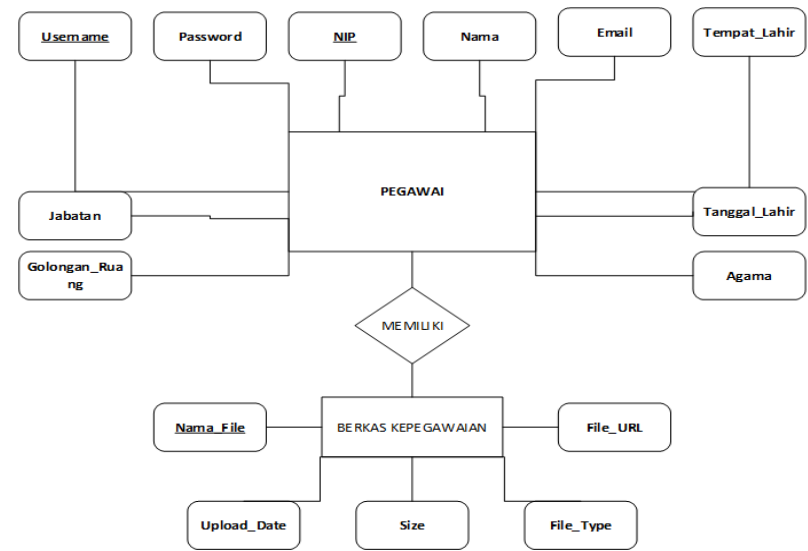

Figure 3. Desain Entity Relationship Diagram

\section{System Interface Design}

The design of the interface consists of the design of the user login page, the design of the admin login page, the design of the user's main menu page, the design of the admin's main menu page, the design page for uploading user documents, the design of the user validation print page, the page design of the admin profile view, and the design of the profile edit page user and admin.

\section{Design Validation}

Product design validation is carried out to provide an assessment of the Integrated Data Bank staffing management information system before an initial trial is conducted. Validation is done in 2 (two) stages, namely product validation / product design and product validation that has been built.

\section{Product Revision}

After the Integrated Data Bank staffing management information system is validated by experts, the next process is the product revision process. The revised part refers to 
suggestions and criticisms from experts in accordance with the results of the questionnaire, namely: Change the location of the button on the login page, main menu and upload documents.

\section{Test Try Products Beginning}

\section{Functionality test}

Testing functionality will test system functionality. Tests carried out by 15 respondents employees at SMK Muhammadiyah Karangpucung by using the test case. The results of the functionality test can be seen in the following Table 1 :

Table 1. The Functionality Test

\begin{tabular}{llcc}
\hline \multirow{2}{*}{ No. Function } & \multicolumn{2}{c}{ Test Results (Respondents) } \\
\cline { 2 - 4 } & Function & Not Functioning \\
\hline 1 & Login & 15 & 0 \\
\hline 2 & Upload file & 15 & 0 \\
\hline 3 & Print validation & 15 & 0 \\
\hline 4 & View profile & 15 & 0 \\
\hline 5 & Edit profile & 15 & 0 \\
\hline 6 & Registration & 15 & 0 \\
\hline
\end{tabular}

\section{Reliability test}

Testing the reliability of the system (reliability test) carried out by the method of stress testing aided software Web Application Performance Testing (WAPT) Pro version 10. The results of the test are shown in the image below .

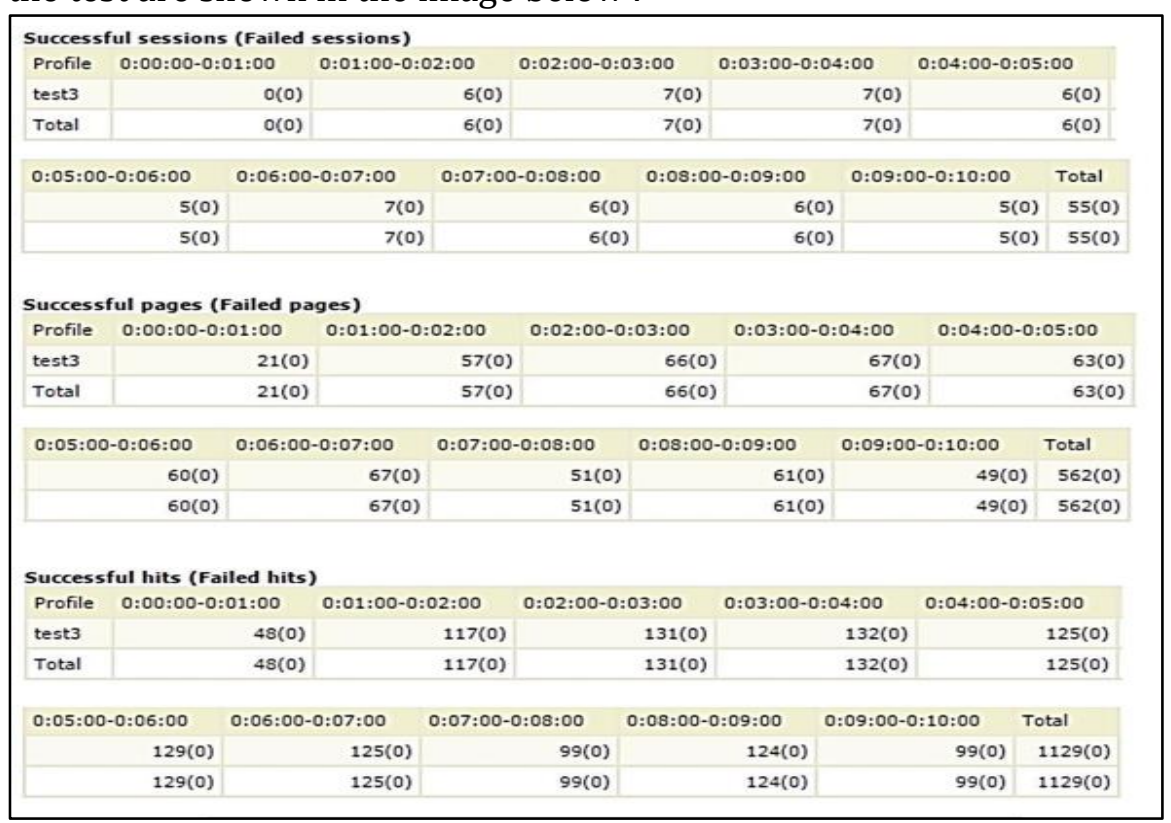

Figure 4. Reliability Test

\section{Reliability test}

Testing the efficiency of the system (efficiency test) done by calculating the time that it takes the system to be loaded in full by the device user included in the answer and process inputs given user. To measure the duration of time that, to use the services of web (web service) GTMatrix especially criteria Page Speed Grade which is a standard assessment of Google in calculating the speed of loading a website. Results efficiency test are shown in the display below. 


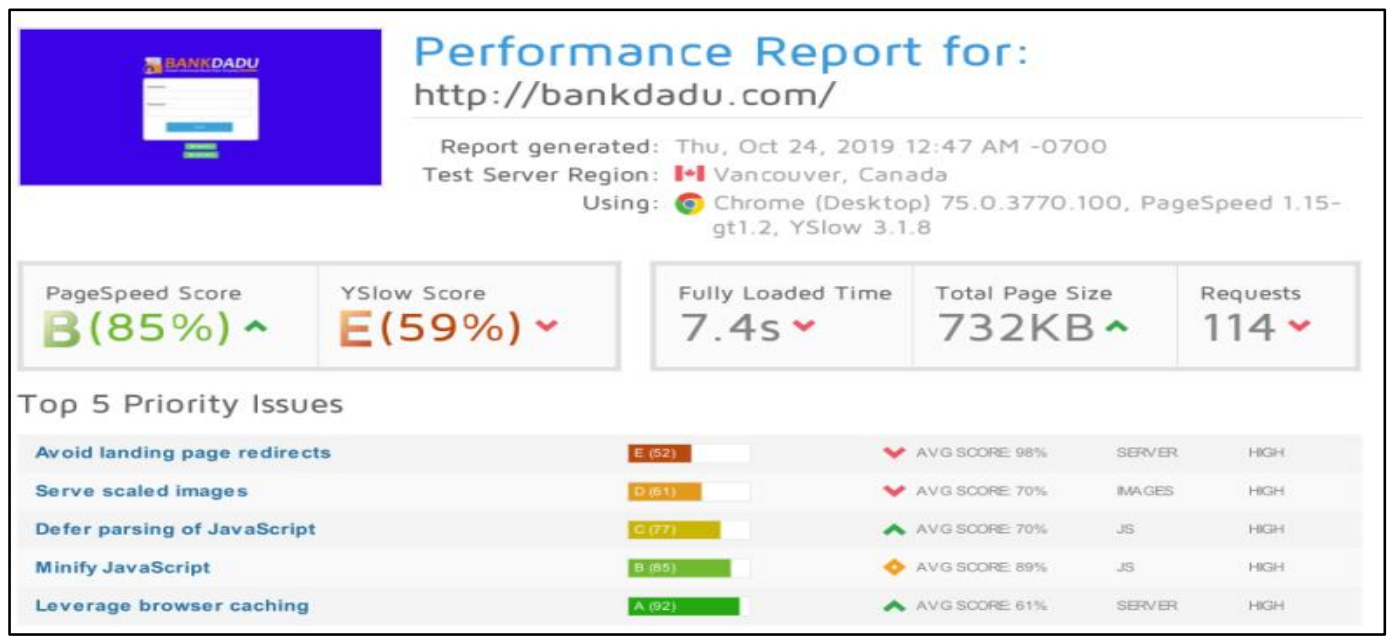

Figure 4. Efficiency Test

\section{Initial Product Revision}

Initial product trial results indicate the product has been tested in terms of functionality, reliability and efficiency. Of the three tests, the product is declared eligible without revision and can proceed to the final product trial.

\section{Test Try Product End}

The product will be tested once again after it was previously tested at the initial product trial stage. In the initial product trial, the product has been tested with functionality, reliability and efficiency tests. While the test try the product end, that will be tested is the usability test (test purposes). At this stage, the product will be tested on 25 respondents which consists of teachers and employees of SMK Muhammadiyah Karangpucung by using a sheet questionnaire Usefulness, Satisfaction and Ease of Use (USE). The results of the questionnaire can be seen in the appendix. Recapitulation of test results can be seen in the following Table 2:

Table 2. Recapitulation of Test

\begin{tabular}{lrrrrr}
\hline \multirow{2}{*}{ Question To- } & \multicolumn{5}{c}{ Number of Respondents } \\
& Score 1 & Score 2 & Score 3 & Score 4 & Score 5 \\
\hline Q1 & 3 & 2 & 7 & 5 & 8 \\
P2 & 6 & 0 & 10 & 6 & 3 \\
Q3 & 3 & 3 & 10 & 5 & 4 \\
Q4 & 2 & 5 & 10 & 5 & 3 \\
Q5 & 4 & 3 & 8 & 5 & 5 \\
Q6 & 3 & 5 & 8 & 4 & 5 \\
Q7 & 2 & 7 & 6 & 6 & 4 \\
Q8 & 4 & 3 & 10 & 5 & 3 \\
Q9 & 5 & 2 & 11 & 2 & 5 \\
Q10 & 4 & 3 & 6 & 5 & 7 \\
Q11 & 1 & 1 & 12 & 3 & 8 \\
Q12 & 2 & 7 & 6 & 6 & 4 \\
Q13 & 2 & 5 & 8 & 5 & 5 \\
Q14 & 4 & 4 & 9 & 4 & 4 \\
Q15 & 6 & 4 & 9 & 1 & 5 \\
\hline
\end{tabular}

Integrated Data Bank Development as Supporting System of Civil Service Management in Middle Vocational School 


\begin{tabular}{lrrrrr}
\hline \multirow{2}{*}{ Question To- } & \multicolumn{5}{c}{ Number of Respondents } \\
\hline Q16 & Score 1 & Score 2 & Score 3 & Score 4 & Score 5 \\
Q17 & 5 & 1 & 13 & 4 & 2 \\
Q18 & 8 & 3 & 9 & 2 & 3 \\
Q19 & 6 & 2 & 9 & 3 & 5 \\
Q20 & 3 & 0 & 13 & 3 & 6 \\
Q21 & 3 & 1 & 8 & 6 & 7 \\
Q22 & 3 & 2 & 5 & 5 & 10 \\
Q23 & 1 & 1 & 10 & 6 & 7 \\
Q24 & 4 & 1 & 7 & 6 & 7 \\
Q25 & 1 & 0 & 12 & 7 & 5 \\
Q26 & 2 & 3 & 12 & 4 & 4 \\
Q27 & 3 & 0 & 7 & 10 & 5 \\
Q28 & 0 & 2 & 11 & 4 & 8 \\
Q29 & 3 & 0 & 9 & 8 & 5 \\
Q30 & 0 & 0 & 7 & 11 & 7 \\
Amount & 0 & 0 & 6 & 11 & 8 \\
\hline
\end{tabular}

\section{Final Product Revision}

The results of the trial of the final product, it was concluded that the product was feasible and no final product revision was needed.

\section{Final Product}

The final product is the result of a series of steps of research methods that have been carried out from starting to discover the potential and problems to the development of the final product in the form of an Integrated Data Bank staffing management information system. This final product is unique and unique because it is tailored to the needs of the Karangpucung Muhammadiyah Vocational School.

\section{Discussion}

\section{Development of an Integrated Data Bank for Staffing Data and Information}

The development of an Integrated Data Bank to provide staffing data and information can be measured through a reliability test. The results of testing the reliability of the system (reliability test) using software WAPT can be seen in the table below:

Table 3. Reliability Test

\begin{tabular}{lllcll}
\hline Category & Success & Failed & $\begin{array}{c}\text { Percentage of } \\
\text { Success }\end{array}$ & $\begin{array}{l}\text { Percentage } \\
\text { Failed }\end{array}$ & Conclusion \\
\hline Sessions & 98 & 0 & $100 \%$ & 0 & Reliable system \\
Pages & 784 & 0 & $100 \%$ & 0 & Reliable system \\
Hits & 2673 & 0 & $100 \%$ & 0 & Reliable system \\
\hline
\end{tabular}

Based on tests of reliability at the top, can be concluded that the system of information management personnel Data Bank Integrated has the reliability that is good and can be relied upon to provide data and information personnel in the use of run length. In addition, based on testing functionality will test system functionality. The test was conducted by 15 employee respondents at SMK Muhammadiyah Karangpucung by using a test case all the features developed were in accordance with their uses.

Development of Support Systems for Data Server and Information Server Usage 
Supporting System Development in this case the use of servers and web hosting systems can be tested through efficiency tests . Testing the efficiency test using GTMetrix gives the results of the PageSpeed Grade B value (85\%) with a loading rate of the system page 7.4 seconds. From these results it can be concluded that the system is included in the efficient category because the loading time is less than 10 seconds. This shows that the system already supports an integrated data bank server at SMK Muhammadiyah Karangpucung.

\section{Development of Accurate Data and Information Services on Personnel Management}

Having conducted the test the usability (usability test) used questionnaires to 25 respondents, obtained the results as follows.

\begin{tabular}{cl} 
Table & 4. Usability Test \\
\hline & Respondents \\
\hline 5 & 162 \\
4 & 157 \\
3 & 268 \\
2 & 70 \\
1 & 93 \\
\hline
\end{tabular}

After going through a statistical calculation then with a percentage of results of $66 \%$, it can be concluded that the Integrated Data Bank staffing management information system can be used as a supporting management system for staff at SMK Muhammadiyah Karangpucung .

\section{Integrated Data Bank Feasibility Testing for Staffing Data and Information}

In addition to the product 's also been through the process of validation of the design , validation of the instrument, and validation of products through the judgment of expert and an expert, who produce the data in the form of Data Flow Diagrams (DFD), the design of the Unified Modeling Language (UML), and the design Entity Relationship Diagram Data Bank Integrated. Based on the results of the product design validity test showed that the layout ( layout ), interface ( interface ), and content ( content) of the system itself obtained a final percentage of $84 \%$.

\section{CONCLUSION}

Based on the results of data analysis and research discussion, it can be concluded that:

1. Integrated Data Bank Services for employee data and information can be used effectively and efficiently. This is based on system reliability with a success rate of $100 \%$ with analysis using WAPT-assisted software.

2. The support system for the use of data and information service servers runs according to the Integrated Data Bank application. In addition, testing the efficiency test using GTMetrix gives the results of the PageSpeed Grade B (85\%) with a loading rate of the system page 7.4 seconds. From these results it can be concluded that the system is included in the efficient category because the loading time is less than 10 seconds.

3. Staffing data and information services can be used as an accurate staffing database. Based on the percentage of usability test results, $66 \%$ of the data show that the Integrated Data Bank staffing management information system can be used as a supporting management system for staff at SMK Muhammadiyah Karangpucung.

Integrated Data Bank Development as Supporting System of Civil Service Management in Middle Vocational School 
4. Integrated Data Bank Products have gone through the process of design validation, instrument validation, and product validation through judgment experts and experts, which produce data in the form of Data Flow Diagrams (DFD), Unified Modeling Language (UML) designs, and Entity Relationship Diagram Bank designs Integrated Data. Based on the results of the product design validity test showed that the layout (layout), interface (interface), and content (content) of the system itself obtained a final percentage of $84 \%$.

\section{ACKNOWLEDGEMENT}

I express my gratitude to the supervisor and to the Regional Leaders of Muhammadiyah who have allowed this research, the teachers and employees of the SMK Muhammadiyah Karangpucung who have assisted the research process so that it runs smoothly.

\section{REFERENCES}

Al Fatah, M. H. 2015. Pragmatic Transfer in Compliment Response Strategies of the English Department Students of the State University of Semarang. English Education Journal, $5(1)$.

Ardhana, K. 2014. Project PHP \& MySQL Membuat Website Buku Digital. Yogyakarta, Jasakom.

Choirudin, R., \& Adil, A. 2019. Implementasi Rest Api Web Service dalam Membangun Aplikasi Multiplatform untuk Usaha Jasa. MATRIK: Jurnal Manajemen, Teknik Informatika dan Rekayasa Komputer, 18(2), 284-293.

Faizal, E. 2018. Sertifikat Hak Cipta-Buku: PEMOGRAMAN JAVA WEB (JSP, JSTL \&SERVLET) Tentang Pembuatan Sistem Informasi Klinik Diimplementasikan Dengan Netbeans IDE 7.2. Dan MySQL.

Gusman, S. A. M. 2017. Manajemen/Administrasi Kepegawaian.

Haryati, S. 2012. Research and Development (R\&D) sebagai salah satu model penelitian dalam bidang pendidikan. Majalah Ilmiah Dinamika, 37(1), 15.

Himawan, D. 2014. Aplikasi Data Mining Menggunakan Algoritma ID3 Untuk Mengklasifikasi Kelulusan Mahasiswa Pada Universitas Dian Nuswantoro Semarang. Semarang: Universitas Dian Nuswantoro.

Lund, A. M. 2001. Measuring usability with the use of questionnaire12. Usability Interface, $8(2), 3-6$.

Luthfia, A. 2014. Kinerja Pegawai Dinas Pendidikan Pemuda Dan Olahraga Kota Pariaman. Jurnal Bahana Manajemen Pendidikan, 2(1), 56-64.

Mulyanto, A. 2009. Sistem Informasi konsep dan aplikasi. Yogyakarta: Pustaka Pelajar, 1, 15.

Nazruddin Safaat, H. 2011. Android: Pemrograman Aplikasi Mobile Smartphone dan Tablet $P C$. Informatika, Jakarta.

Priambodo, S. 2007. Sistem Informasi Manajemen Kepegawaian Badan Kepegawaian Daerah (BKD) Kabupaten Purbalingga. Universitas Negeri Semarang.

Sugiyono, M. P. P. 2016. Pendekatan Kuantitatif, Kualitatif, dan $R \&$ D (cetakan ke-23). Bandung: Alfabeta.

Sugiyono, P. 2015. Metode penelitian kombinasi (mixed methods). Bandung: Alfabeta.

Tim, E. 2016. All in One Web Programming: Elex Media Komputindo.

Abidin, Zaenal. 2014. Analisa Sistem Informasi. Sukabumi: Al Fath Zumar.

Volume 3, Number 2, Nov 2020 
Alfatah, Muhammad. 2014. Sistem Informasi Kepegawaian Berbasis Website di SMP Eka Sakti Semarang. Semarang: Fakultas Ilmu Komputer, Universitas Dian Nuswantoro Semarang.

Amir E. Sarabadani Tafreshi (B), Kim Marbach, and Moira C. Norrie. 2017. Proximity-Based Adaptation of Web Content on Public Displays, 17th International Conference, ICWE 2017

Andri Feriyanto dan Endang Shyta Triana, 2015. Pengantar Manajemen (3 In 1) untuk Mahasiswa dan Umum, Mediatera, Yogyakarta.

Coronel, Carlos, \& Morris Staven. 2016. Database Systems, Design, Implementation, and Management (12th ed.). Canada: Cengage Learning

Depdikbud. 1989. Kamus Besar Bahasa Indonesia. Jakarta: Balai Pustaka

Ericson, Elias. 2017. Learn WordPress From beginner to advanced user

Erwandy, D., Sugiharto, A., Permana, E.J. 2015. Perancangan Sistem Informasi Manajemen Data Kepegawaian Berbasis Web (Studi Kasus: Uptd Pendidikan Kec. Cikatomas Kabupaten Tasikmalaya). Tasikmalaya: Teknik Informatika, STMIK Tasikmalaya.

George R. Terry, Leslie W. Rue. 2016. Dasar-Dasar Manajemen. PT. Bumi Aksara, Jakarta

Hartoo. 2016. Manajemen Sumber Informasi Perpustakaan. Yogyakarta: Calpulis

Hamalik, Oemar. (1993). Pengolahan Sistem Informasi. Bandung: PT. Trigenda Karya.

IG, Wursanto. 1988. Manajemen Kepegawaian 2. Yogyakarta: Kanisius

Keputusan Menteri Dalam Negeri Nomor 17 Tahun 2000 tentang Sistem Informasi Manajemen Kepegawaian Depdagri dan Pemda.

Lutfhia, Anggi. (2014). Kinerja Pegawai Dinas Pendidikan Pemuda dan Olahraga Kota Pariaman. Jurnal Administrasi Pendidikan, Bahana Manajemen Pendidikan, Volume 2 Nomor 1, Juni 2014.

Mulyanto, Agus. (2009). Sistem Informasi Konsep \& Aplikasi. Yogyakarta: Pustaka Pelajar.

Ramadhan, Taopik \& Cahyana, Rinda. (2016). Pengembangan Sistem Informasi Kepegawaian pada Dinas Perindustrian Perdagangan dan Pengelolaan Pasar Kabupaten Garut. Jurnal Algoritma Sekolah Tinggi Teknologi Garut, ISSN: 2302-7339 Vol. 13 No. 1 2016, 164-169.

Ramadhan, Taopik, \& Cahyana, Rinda. (2016). Pengembangan Sistem Informasi Kepegawaian Pada Dinas Perindustrian Perdagangan Dan Pengelolaan Pasar Kabupaten Garut. Jurnal Algoritma Sekolah Tinggi Teknologi Garut, ISSN: 2302-7339 Vol. 13 No. 12016.

Safaat, Narzudin. (2015). Rancang Bangun Aplikasi Multiplatform. Bandung: Informatika

Saputra, Tera. (2017). Pengaruh Penerapan Sistem Informasi Manajemen Kepegawaian (Simpeg) Dalam Meningkatkan Kinerja Pegawai Pada PDAM Tirta Kencana Samarinda. E-Journal Administrasi Bisnis, 2017, 5 (2): 338 - 350 ISSN 2355-5408.

Sugiyono. 2015. Metode Penelitian Kuantitatif Kualitatif dan R\&D. Bandung: Alfabeta

Sukardjo. 2012. Buku Pegangan Kuliah Evaluasi Pembelajaran IPA. Program Studi Pendidikan Sains Program Pascasarjana UNY.

Supardy, Setia \& Bayu, Yudhantoro. (2014). Sistem Informasi Kepegawaian. Jakarta: Pusat Pembinaan Jabatan Fungsional Kepegawaian Badan Kepegawaian Negara

Tomlinson, Todd. 2015. Beginning Backdrop CMS. Oregon: Apress

Integrated Data Bank Development as Supporting System of Civil Service Management in Middle Vocational School 